\title{
MEDITERRANEAN CYCLONE WITH AN ATYPICAL TRAJECTORY: CHARACTERISTICS AND OUTCOME (12-14 NOVEMBER 2016)
}

\author{
D.R. MANTA ${ }^{1}$, A.A. TIŞCOVSCHI ${ }^{1}$, Z. ŞIPOS ${ }^{2}$, Raluca-Maria ŞTEFAN $^{3}$
}

\begin{abstract}
Mediterranean cyclone with an atypical trajectory: Characteristics and outcome (12-14 november 2016). It is not uncommon for trajectories of Mediterranean cyclones to steer away from the traditional paths identified by specialists. In most cases, Mediterranean depressions bypass the Romanian Carpathian Mountains barrier either in the south or west, which results in the fact that only certain regions are affected by associated phenomena. The interval 12-14 November 2016 was notable in that the entire Romanian territory experienced a vast array of meteorological phenomena linked to the irregular trajectory of a Mediterranean cyclone. The cyclone initially moved along a classic trajectory 4a, after which veered into 1c. The cyclogenesis onset and trajectory were mainly determined by altitude conditions, and the rapid deepening in the Moldavian region was due to several factors acting simultaneously. Precipitation was recorded throughout the country's territory in the aforementioned interval. In the northern half of the country there were frequent exceedances of $25 \mathrm{~mm}$ in 72 hours, up to $85 \mathrm{~mm}$ in northern Moldavia. It snowed and the season's first snow cover was recorded in extensive areas in Transylvania and northern Moldavia, as well as in limited areas in Maramureş, Banat and Crişana, and blizzards were reported sporadically. In the mountains, the snow cover thickness reached $48 \mathrm{~cm}$ in 24 hours. Sustained winds intensified rapidly in Oltenia, Muntenia and Dobrogea, as speeds exceeded $80 . . .90 \mathrm{~km} / \mathrm{h}$ in lowlands, and $120 \ldots 130 \mathrm{~km} / \mathrm{h}$ in high mountainous regions, where the blizzard was particularly strong, with reduced or zero visibility. Scattered heavy rain showers, lightning and storm-like winds were reported in Dobrogea. In terms of thermal regime, most of the country shifted from slightly above normal to significantly below average temperatures. In most regions, peak air temperature values decreased by over $10{ }^{\circ} \mathrm{C}$ within 24 hours, and several all-time daily lows were recorded. The negative effects were significant. Several roads were closed due to the snow cover and wind-fell trees, material damages were recorded, and 3 people were killed.
\end{abstract}

Key words: atypical trajectory, cyclogenesis, altitude

\section{INTRODUCTION}

The evolution of Mediterranean cyclones in the Balkan space has always had a significant importance to authors from countries in which weather phenomena associated to these baric centres had catastrophic effects. Once the European meteorological network was established, the Mediterranean Sea's 
cyclogenesis potential could be captured and transposed in a database that helped generate the first studies on the evolution, trajectories and effects of Mediterranean cyclones. While Romania is not a Mediterranean country, the importance of Mediterranean cyclogenesis is outstanding.

Most major meteorological phenomena (heavy precipitation, high wind intensification, blizzards, heavy snowfall, etc.) are caused by Mediterranean cyclones that cross the Balkan Peninsula along certain trajectories. Depending on these routes, identified by Şorodoc (1962) and updated by Bordei (1983), the phenomena have different intensities, affect the country's regions differently, and shows a differentiated diversity. This study approaches the issue of a Mediterranean cyclone that moved along an atypical trajectory, which we found to resemble two trajectories noted by Bordei (1983) based on Şorodoc's (1962) initial work, i.e. 4a and 1c. This depression trajectory determined heavy precipitation and blizzards in the centre of Romania, strong wind gusts in southern and eastern Romania, significant country-wide cooling, and storms in Dobrogea - i.e. a wide range of meteorological phenomena. The negative effects were significant. Three people were killed, and most country regions reported serious material damages.

\section{DATA AND METHODS}

This study entailed synoptic and mesoscale analysis. The following were used for the synoptic analysis: mean sea level pressure maps, different geopotential levels (300, 500, 850, $1000 \mathrm{hPa}$ ), satellite imagery (Water Vapour) in order to determine the intrusion of stratospheric air in the cyclogenesis process. The data were obtained from the Eumetrain platform, coupled with results generated by the global numerical forecast model ECMWF (European Centre for Medium-Range Weather Forecasts). The mesoscale analysis interpreted and used data recorded by weather stations of the National Meteorology Administration network (A.N.M.), outputs and analyses of small-scale numerical forecast models of A.N.M. (COSMO, ALARO), and hourly maps to determine the cyclone's evolution on Romanian territory.

\section{AEROSYNOPTIC SETTING}

Throughout the continent, the beginning of November was characterized by a dominantly zonal circulation, fairly weak in the middle and high troposphere. Gradually, the circulation intensified, and a high amplitude through formed above Western Europe. Thus, in the Mediterranean Sea area, the polar jet-stream advanced towards the subtropical jet-stream, and favorable conditions for cyclogenesis resulted on the through's downstream side (fig. 2), which, in this instance, consisted of the deepening of a weakly-shaped low that originated in the south-east of the North Sea.

The depression appeared in the vicinity of the Gulf of Genoa, and the contribution of the cyclogenesis factor from the lower troposphere, i.e. advection of 
cold air in Rhone Valley, was low. Both the cyclone formation and its atypical trajectory in the following days were mainly determined by altitude conditions. The significant decrease of ground-level pressure (generally $-1,0 \ldots-2,6 \mathrm{hPa} / 3$ hours) started in the first half of November 11th, when a short-wave through started to develop in the middle troposphere, which determined a substantial cyclonic vorticity advection on its east side (fig. 1 - right).

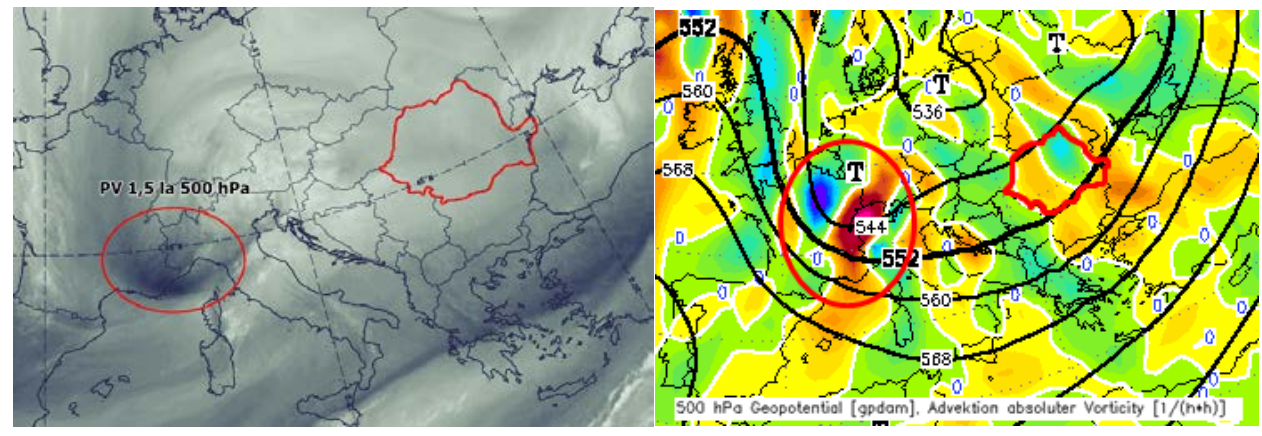

Fig. 1. Wv 6.2. Satelitte imagery (left); $500 \mathrm{hPa}$ advection of vorticity and geopotential height (right) $-11^{\text {th }}$ of nov. 2016, 06 UTC (Source: www.eumetrain.org / www.wetter3.de)

The pressure decrease was subsequently maintained and intensified by the divergence in the upper troposphere, especially in the north of the Adriatic Sea. The cyclogenesis process can also be visualised on Water Vapour satellite imagery (fig. 1 - left), where dark grey areas indicate the intrusion of stratospheric air in the upper troposphere.

The cyclone rapidly crossed the Balkan Peninsula without a significant increase in central pressure, even though crossing a mountainous area usually results in a forward movement speed decrease, isobar distortion, and a more pronounced increasing pressure due to increased friction. In this instance, the altitude had a bigger impact - $500 \mathrm{hPa}$ through in the geopotential field, located behind the ground cyclone, and favourably phase-displaced in relation to the thermal through, as did the strong divergence in the upper troposphere, located north-east of the ground depression's position.

The cyclone crossed Romania along an approximate south-west-north-east trajectory, on which orography had a minimal effect. Once it reached Moldavia, the cyclone deepened rapidly, and its central pressure reached the lowest value of its life cycle. Both the atypical trajectory and the cyclone deepening were due, in addition to maintaining the afore mentioned vertical structure, to the overlap of the cyclone advection area of a strong, differentiated thermal advection, and an increase in thermal asymmetry in lower layers, and the divergence from high troposphere. When it reached Ukraine, the depression occluded rapidly, a process which was also made apparent by the vertical axis angle decrease. 


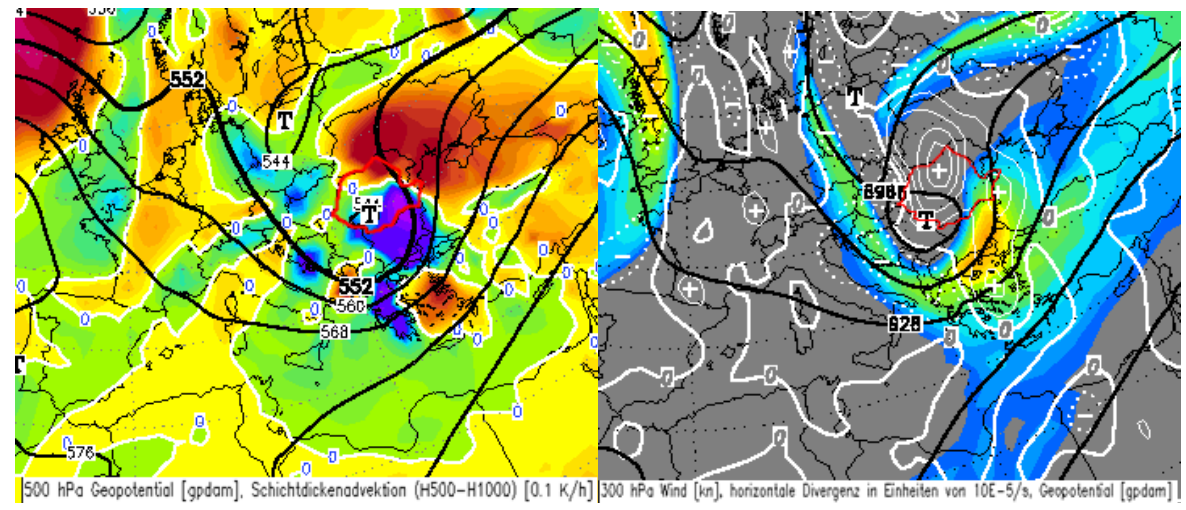

Fig. 2. 500 hPa geopotential (black lines) and 1000-500 hPa advection of relative topography (left); 300 hPa wind speed (colored), geopotential (black lines) and divergence (right) $-13^{\text {th }}$ of nov. 2016, 00 UTC (Source: www.wetter3.de)

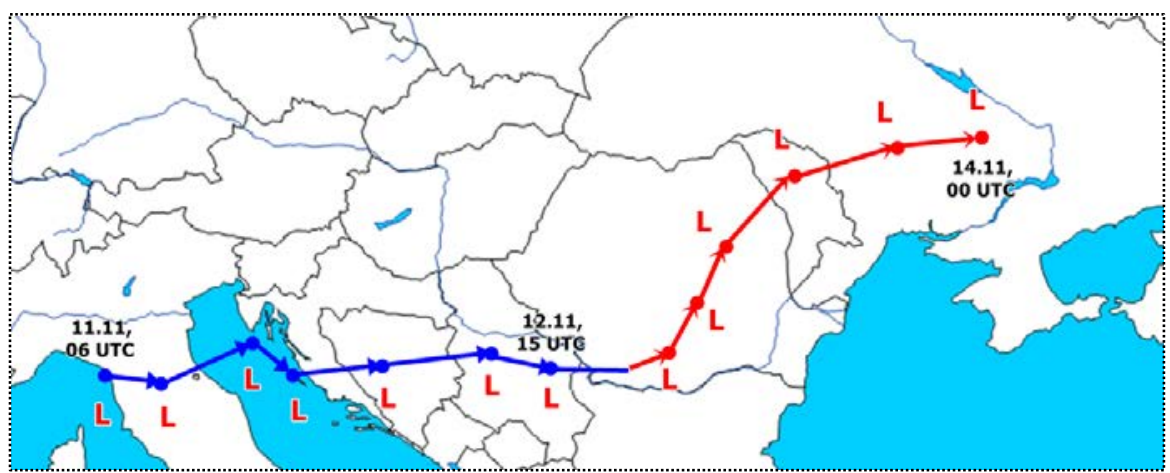

Fig. 3. The Genoa low trajectory (blue line - 4a trajectory and red line - 1c trajectory)

\section{MESOSCALE ASSESSMENT}

Upon a mesoscale analysis of the mean sea-level pressure field and $850 \mathrm{hPa}$ temperature (it was noticed that, on the night between November 12th and 13th, a secondary depression nucleus was temporarily formed in Transylvania. This phenomenon is not uncommon. The mesoscale cyclone appears when, in the lower troposphere, below mountain ridge level, the Transylvanian Depression is gradually surrounded by cold air, first noted by Bordei E. and Bordei I., 1970 and reviewed in 1986. The low-pressure area (fig. 4) is located in the isolated warm air mass in the Transylvanian Plateau, around which the cold air moves in a divergent orography-forced manner. Even though the cold air mass eventually gets in and forces the vertical evacuation of the warm air, this ascending movement favours the increase of precipitation amounts. At the same time, the small-scale cyclone is entrapped rapidly and disappears off synoptic maps. 

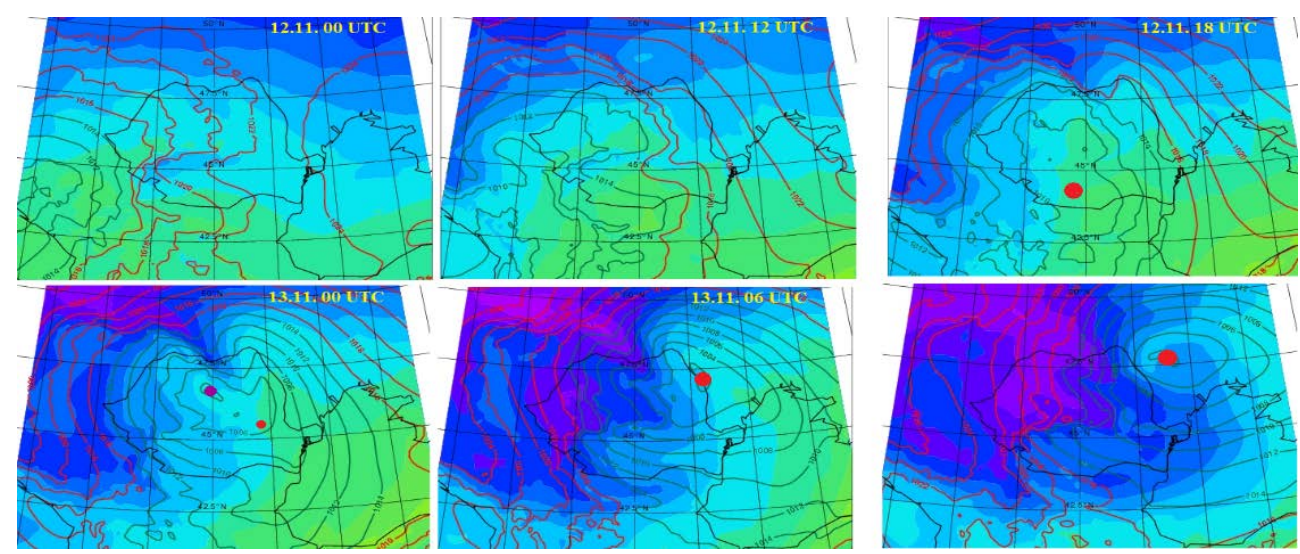

Fig. 4. Evolution of MSLP (hPa, black lines) and $850 \mathrm{hPa}$ temperature (colored) between $12^{\text {th }}$ of November 2016, 00 UTC $-13^{\text {th }}$ of November 2016, 12 UTC (Source: National Meteorological Administration)

\section{SEQUENCE OF EVENTS}

As the cyclone came closer to the Balkan Peninsula, the baric gradient increased between Banat and Oltenia. On November 12th, at 02:00, the low sealevel pressure was 1020,0 hPa at Apa-Neagră and 1014,5 hPa at Oravița, which are located approximately $70 \mathrm{~km}$ apart. The wind intensified from the ESE sector, and a local wind called Coşava happened for an interval of at least 8 hours. Wind gust speed reached $23 \mathrm{~m} / \mathrm{s}(83 \mathrm{~km} / \mathrm{h})$ at Oravița and $22 \mathrm{~m} / \mathrm{s}(79 \mathrm{k} / \mathrm{h})$ at Moldova Veche. It rained in the country's south-western region from the warm front's cloud system, but precipitation amounts did not exceed $12,4 \mathrm{~mm}$. The precipitation area gradually expanded. In the beginning, there was only rain in lowlands, with heavy downpour in the south-west, at first, then in Dobrogea as well, where scattered lighting and convective wind gusts were recorded. It snowed in the high mountainous region. There were heavy blizzards on mountain ridges - Țarcu weather station recorded wind speeds of $32 \mathrm{~m} / \mathrm{s}(115 \mathrm{~km} / \mathrm{h})$. Until 20:00, precipitation amounts totaling 24 $\mathrm{mm}$ were recorded at Cuntu and, by next morning, the precipitation area grew countrywide (fig. 5 - left). There were scattered values that exceeded $25 \mathrm{~mm}$, and even $50 \mathrm{~mm}$ in south-western mountainous areas. The peak value $(55,3 \mathrm{~mm})$ was recorded at Cuntu weather station, in Caraș Severin County, until the morning of November 13th. The snow area gradually expanded and eventually encompassed the entire mountainous region; during night-time, it also snowed locally in Banat, Crișana, Maramureș and Transylvania (fig. 6 - left). The movement of the depression nucleus generated a differentiated temperature evolution. In the south and south-east, in the cyclone's warm sector (fig. 5 - left), the weather got warmer, with temperature peaks up to $6,4 \mathrm{C}$ higher than the previous day, as recorded at Zimnicea. This is also where the highest temperature of the day was recorded: 20,1 $\square \mathrm{C}$, which exceeded the multiannual mean value by $9,9 \square \mathrm{C}$. 

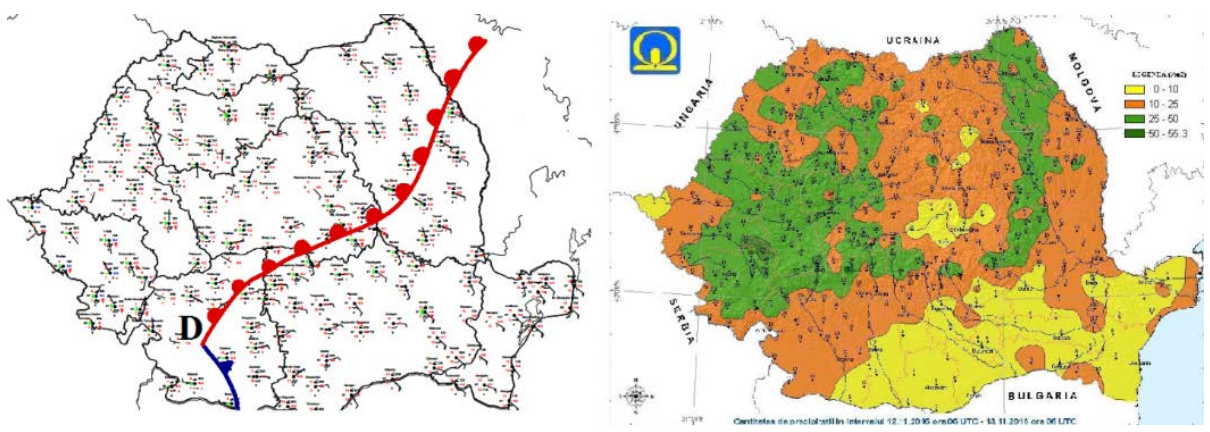

Fig. 5. Ground level synoptic map (left) $-12^{\text {th }}$ of November 2016, 18 UTC; Accumulated precipitation in the last $24 \mathrm{~h}$ (right) $-13^{\text {th }}$ of November 2016, 06 UTC (Source: National Meteorological Administration)

In the rest of the country the weather cooled down, and the most intense cold air penetration occurred in northern Moldavia, as Drăghici I. noted in 1988 (fig. 6 - right). The peak temperature at Rădăuți was $1,9 \square \mathrm{C}$, which deviated from the multiannual mean value by $-6,3 \square \mathrm{C}$. In the following 24 hours, the cyclone moved towards the centre of Moldavia, and the depression nucleus exited the Romanian territory in the second half of November 13th. The pressure increased rapidly, and the depression was closely followed by a strong cold air advection area. Temperatures kept dropping countrywide, with peak temperatures up to 12 $\square \mathrm{C}$ lower than the previous day. Maximal temperatures ranged from $-3,6 \square \mathrm{C}$ at Dumbrăvița de Codru (Bihor County) to $10,6 \mathrm{C}$ at Sulina, all of them under multiannual mean values, some of which were record lows for November 13th. In the north of Botoşani county $44 \mathrm{~mm}$ of rain fell, but generally, the precipitation amounts were close to $10 \mathrm{~mm}$. At 20:00 a snow layer had formed in the mountains (61 cm at Bâlea Lac), in Maramureș, Transylvania and locally in Crișana, Banat and northern Moldavia.
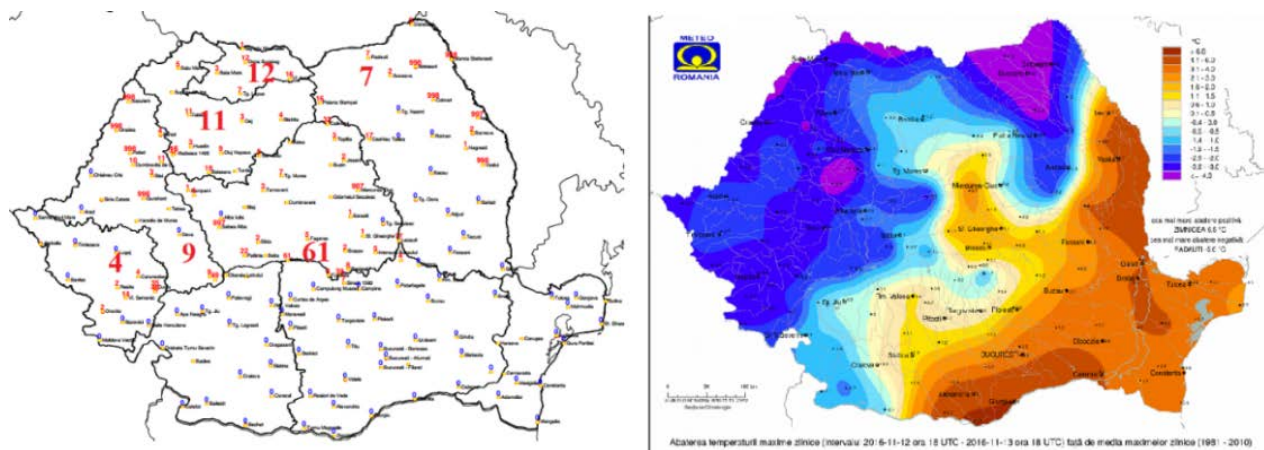

Fig. 6. Snow depth (left) $-13^{\text {th }}$ of November 2016, 18 UTC; High temperature deviation against the multiannual mean (right) - $13^{\text {th }}$ of November 2016 (Source: National Meteorological Administration) 
Wind intensified countrywide, from the NNW sector in Moldavia, and mainly WSW in the rest of the country. On November 13th, peak wind gust speeds of $20 \mathrm{~m} / \mathrm{s}(72 \mathrm{~km} / \mathrm{h})$ were recorded at Slatina, Deva, Vaslui, Roman, Bucharest Filaret, Negrești, Corugea, Brașov and Batoș, $21 \mathrm{~m} / \mathrm{s}(76 \mathrm{~km} / \mathrm{h})$ at Sf. Gheorghe (delta), Giurgiu, Turnu Măgurele, Videle, Cernavodă, Caracal, Slobozia, Sărmașu, Rădăuți, Bechet, Băilești, Sinaia and Rădăuți, $22 \mathrm{~m} / \mathrm{s}(79 \mathrm{~km} / \mathrm{h})$ at Calafat, Sebeș, Jurilovca, Târnăveni, Ceahlău Toaca, $23 \mathrm{~m} / \mathrm{s}(83 \mathrm{~m} / \mathrm{s})$ at Oltenița, Zimnicea, Călărași, Gura Portiței, Drăgășani, Sulina and Stânca Ștefănești, 24 m/s $(86$ km/h) at Adamclisi, Mangalia, Medgidia and Mahmudia, $25 \mathrm{~m} / \mathrm{s}(90 \mathrm{~km} / \mathrm{h})$ at Alexandria, Craiova and Roșiorii de Vede, $26 \mathrm{~m} / \mathrm{s}(94 \mathrm{~km} / \mathrm{h})$ at Baraolt, Fetești and Cotnari, 29 $\mathrm{m} / \mathrm{s}(97 \mathrm{~km} / \mathrm{h})$ at Penteleu, $31 \mathrm{~m} / \mathrm{s}(112 \mathrm{~km} / \mathrm{h})$ at Bisoca, $34 \mathrm{~m} / \mathrm{s}(122 \mathrm{~km} / \mathrm{h})$ at Lăcăuți, $35 \mathrm{~m} / \mathrm{s}(126 \mathrm{~km} / \mathrm{h})$ at Vf. Omu and $28 \mathrm{~m} / \mathrm{s}(137 \mathrm{~km} / \mathrm{h})$ at Țarcu. There were severe snow blizzards and drifting in the mountains, with $170 \mathrm{~cm}$-high snowdrifts at Omu weather station.

\section{CONCLUSIONS}

The high strong gusts from the western sector in the south of the country, and from the north-western sector in Moldavia was caused by the deepening of a depression of Mediterranean origin especially from altitude conditions. Although this cyclone was formed near the regular area in the Gulf of Genoa, the most significant pressure decrease and baric gradient increase occurred on Romanian territory. Due to the atypical trajectory the cyclone followed, all national regions were affected, and the weather changed abruptly. In the south and east, high wind intensification caused the death of three people and massive material damages, while inside the Carpathian arch and subsequently in northern Moldavia blizzards and fallen trees caused traffic difficulties on several roads. In Dobrogea, this wide range of meteorological phenomena also included thunderstorms coupled with convective wind gusts.

\section{REFERENCES}

1. Bordei, E.I. (1983) - The role of the Alpine-Carpathian mountain chain for the evolution of the Mediterranean cyclones. Editura Academiei R.S.R., București, România

2. Drăghici, I. (1988) - Atmospheric Dynamics, Editura Tehnică, Bucureşti, România

3. Şorodoc, C. (1962) - Development and evolution of the Mediterranean cyclones and their influence upon the weather conditions in Romania., Culegere de lucrări a institutului meteorologic pe anul 1960, București

4. ***Baza de date a Administrației Naționale de Meteorologie

5. http://wetter3.de accesed on January, 5, 2017

6. http://eumetrain.org accesed on January, 10, 2017 